\title{
7. APTYCHI (AMMONOIDEA) FROM THE LATE JURASSIC AND EARLY CRETACEOUS OF THE EASTERN ATLANTIC, DSDP SITE 367
}

\author{
Otto Renz, Museum of Natural History, Basel, Switzerland
}

The exact stratigraphic range of numerous species and groups of aptychi is at present still unsatisfactorily known, and they are therefore often considered to be of subordinate value for stratigraphic correlations and for biostratigraphic subdivisions. This occurs because aptychi were generally preserved under special ecological circumstances, which were unfavorable for the preservation of age-indicative ammonite shells. Ideal, but rarely observable, conditions are found for instance in the Late Jurassic of Solnhofen in southern Germany, where numerous aptychi are preserved in their natural position within the body chambers of their corresponding ammonites. In the Alpine-Mediterranean facies province, however, where abundant aptychi are found, such favorable conditions did not exist. The water depth of the Tethyan Ocean during Late Jurassic and Early Cretaceous times remained mostly below the carbonate compensation depth (CCD), where ammonite shells are rarely found intact. Therefore the classification of aptychi has to be considered as tentative, and at present not adjustable to the taxonomy of the Ammonoidea. Due to the incomplete knowledge of their stratigraphic ranges, our ideas on the evolution of most of their morphological features must be considered provisional.

The core material obtained by the Deep Sea Drilling Project provides an exceptional opportunity to obtain data elucidating the problems connected with the stratigraphic succession of aptychi assemblages. This report indicates that a more reliable picture concerning the stratigraphic position of aptychi can be obtained. This could finally provide us with correlations based on aptychi of the Late Jurassic and Early Cretaceous sequences in the wells drilled by DSDP. The present results, which might contribute towards this final aim, concern material from Site 367, situated in the Cape Verde Basin, southeast of the Cape Verde Islands. The studies concerning the stratigraphic sequence of aptychi in the Carpathians by Gasiorowski (1962) were most useful for the age determinations of the species found at Site 367.

The preservation of thin-shelled, very fragile valves is generally not optimal, as often they were broken in numerous small fragments during compaction of the sediments. It has been necessary to embed the valves in plaster, especially when the concave sides are exposed. In the Rosso ad Aptichi facies the sediment often sticks to the surface of the valves and is difficult to remove. This is especially the case with forms having ornamented surfaces, as is the case with Granulaptychus. A similar difficulty has been encountered with aptychi from surface outcrops of this facies type.

A serious handicap arises when valves are cut during the splitting of the cores, The fragments available for investigation are generally insufficient to permit a reliable reconstruction.

In samples from Site 367 the valves are in general smaller than those present from Leg 11, Site 105, in the northwestern Atlantic (Hatteras Abyssal Plain, Renz, 1972). Juvenile stages occur abundantly in which case determinations often remain doubtful, as not all features present on an adult specimen are developed in the juvenile stage.

The aptychi investigated in this report are distributed within a sedimentary column of about 220 meters. Within this sequence the samples which contain aptychi comprise four sampled intervals totaling about 15 meters. The overall thickness of the 25 samples available amounts to only $25 \mathrm{~cm}$. It is thus obvious that the results are to be considered as fragmentary and preliminary. The prospects that more accurate age assignments might be possible in the future look promising.

The following discussions of all recognizable fragments has been arranged stratigraphically through the cores from the oldest to the youngest (Figure 1).

\section{SAMPLE 367-36-2, 72-73 CM}

The sediment is a dark, wine-red, argillaceous limestone comparable to the Rosso ad Aptichi facies of the Mediterranean province. It is composed of carbonates $(64 \%)$ and of iron-rich clay material containing very small angular quartz grains and abundant mica flakes. Besides the Laevaptychus, numerous fragile plates of calcite derived probably from jaw parts of cephalopods occur. Several are reproduced on Plate 2, Figures 12, 13. The outlines of some of these plates resemble the problematica described from Site 99A, Leg 11, Sample 99A-14-2, 23$25 \mathrm{~cm}$ (Renz, 1974, p. 517, fig. 5 and pl. 2, fig. 1-4). Radiolaria were not observed.

\section{Laevaptychus mexicanus (Castillo y Aguillera)}

(Plate 1, Figures 1a, b)

Aptychus mexicanus Cast. y Aguil., 1895, p. 45, pl. 22, fig. 8, Holotype.

Laevaptychus mexicanus Cast. y Aguil., 1931, Trauth, p. 131, fig. C 14.

Section $367-36-2,72-73 \mathrm{~cm}$ is a well-preserved, isolated left valve. Its ventral half has been cut off when sawing the core. An attempted reconstruction of this compact form is based on the broad concentric growth segments exposed on the concave side. They follow the outline of the valve and are subdivided in narrowly spaced fine growth lines. The reconstruction gives a width-index (W:L) of about 0.82 against 0.86 , and an apical angle of $105^{\circ}$ against $90^{\circ}$ on the Mexican specimen. Noteworthy are the pore openings on the 


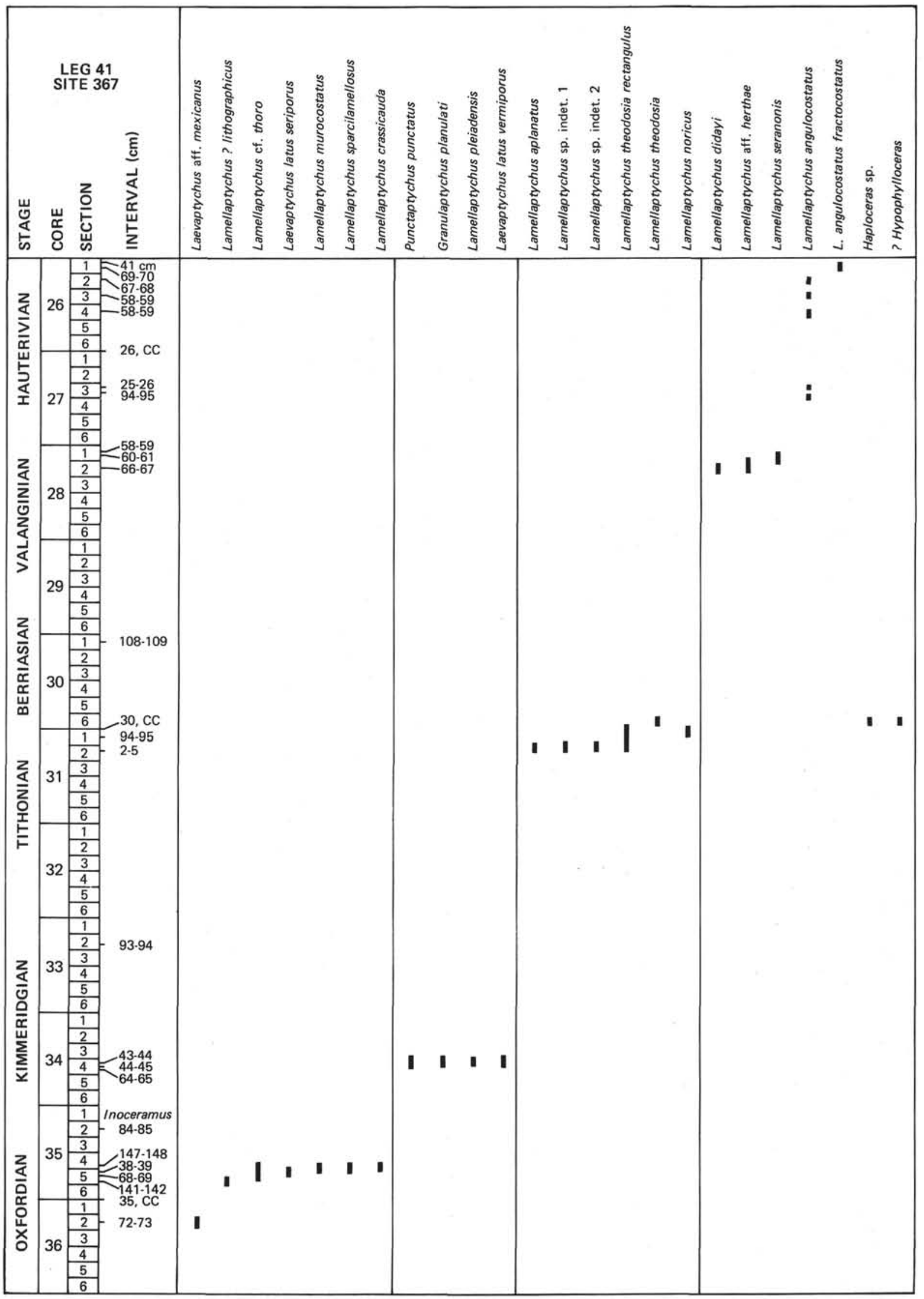

Figure 1. Stratigraphic distribution of aptychi in the late Jurassic and early Cretaceous from Leg 41; Site 367, DSDP (uncored intervals not indicated). 
convex surface, which are very widely spaced and rounded to oval (Plate 1, Figure 1b).

The holotype is derived from the Late Jurassic of the Sierra Catorce in the Mexican State of San Luis Potosí. Unfortunately more detailed information regarding its stratigraphic position has not been given. Its position is 3.80 meters below the level of Core 367-35, which contains an assemblage of late Oxfordian forms, thus we assume an Oxfordian age for this specimen as most likely.

\section{SECTIONS 367-35-4 AND 367-35-5}

The three samples available consist of gray, rather soft calcilutites, with carbonate contents varying between $42 \%$ and $47 \%$. A significant change in facies must take place within an interval of 3.80 meters, separating the present samples from the preceding one, containing Laevaptychus mexicanus. Only 2.62 meters above the present interval of gray calcilutites, Sample $35-2,84-85 \mathrm{~cm}$ displays again the typical red facies, which here contains fragments of Inoceramus but no aptychi. Worth mentioning is a peculiar sedimentary feature found in Sample 35-5, $38-39 \mathrm{~cm}$, which is provisionally discussed in the Appendix to this report (Plate 2, Figures 14-17).

\section{Laevaptychus latus seriporus Trauth \\ (Plate 1, Figures 2a, b)}

Aptychus latus Park., Favre, 1880, p. 45, pl. 3, fig. 12 (non fig. $11=$ L. latus).

Laevaptychus latus var. seripora, Trauth, 1931, p. 77, pl. 1, fig. 5 .

Sample $367-35-5,68-69 \mathrm{~cm}$ : The dorsal half of this left valve has been cut off by splitting the core. The important features are small, rounded to elongated pores arranged along concentric rows around the apex (Plate 1, Figure 2b). About five such rows of pores are recognizable on the convex surface. These pores are generally small and become larger and polygonal towards the lateral facet. The width-index (W:L), after an attempted reconstruction, amounts to 0.59 , against 0.70 for a specimen figured by Favre (1880), derived from the Tithonian in the Canton Fribourg in Switzerland. Similar specimens have been described also from Solnhofen in southern Germany, where they occur in the Oxfordian as well as the Kimmeridgian (Malm zeta) (Trauth, 1931, p. 78).

\section{Lamellaptychus ef. thoro (Oppel)}

(Plate 1, Figures 3-6)

Lamellaptychus thoro (Oppel), Trauth, 1938, p. 183, pl. 13, fig. 4 , cum synon.

Lamellaptychus thoro (Oppel), Gasiorowski, 1962, pl. 4 , fig. 9 .

Lamellaptychus thoro (Oppel), Renz, 1974, p. 515, pl. 2, fig. 5

Samples 367-35-5, 141-142 cm and 367-35-4, 147-148 $\mathrm{cm}$ : Abundant, fragile, juvenile valves occur which are difficult to free from the sediment. The best preserved examples were obtained from Samples 367-35-4, 147$148 \mathrm{~cm}$, where most of the specimens seen belong to this group. Very similar, if not identical forms from Sample 99A-14-2, 23-24 cm, situated north of the Bahamas, have been assigned to this form. The laminae exactly follow the lateral and ventral margins of the valve, and they meet the symphysis with acute angles ranging between $60^{\circ}$ and $70^{\circ}$. The width-index, according to Trauth (p. 184), varies between 0.40 and 0.70 compared with 0.53 to 0.56 for the present specimens.

L. thoro is known from the Oxfordian and Kimmeridgian in southwestern Germany (Malm alfa to zeta). Further it has been mentioned by Trauth from the Tithonian near Vienna, and by Gasiorowski (1962) from the Carpathians in the Oxfordian within the horizons II and III (not VI as erroneously mentioned by Renz, 1974).

\section{Lamellaptychus ? lithographicus (Oppel) \\ (Plate 1, Figures 7a,b)}

Aptychus von Ammonites lithographicus Oppel, 1863, p. 249 , pl. 68 , fig. 2,3 .

Aptychus sp. ind., Favre, 1876, p. 63, pl. 6, fig. 12. Lamellaptychus lithographicus (Oppel), Trauth, 1938, p. 181, pl. 13, fig. 1, cum synon.

Lamellaptychus lithographicus (Oppel), Gasiorowski, 1962, pl. 4, fig. 10.

Sample $367-35-4,147-148 \mathrm{~cm}$ : One specimen which has been cut diagonally when splitting the core might be assigned to this species. A reconstruction of the valve has been attempted, but the evidence is insufficient. The lamellae parallel the lateral margin and seem to meet the symphysis with acute angles. The widthindex of L. lithographicus varies according to Trauth (p. 182) between 0.40 and 0.50 , compared with 0.41 for the present reconstruction.

In southern France (Dép. Ardèche) L. lithographicus occurs in the Oxfordian (Dumortier and Cotteau, 1871) and in Solnhofen in the Malm zeta (Kimmeridgian) (Steinmann, 1907). From the Carpathians, Gasiorowski mentioned it from the Oxfordian, together with L. thoro (horizons II and III).

\section{Lamellaptychus ef. crassicauda (Quenstedt)}

(Plate 1, Figures 11, 12)

Aptychus crassicauda Quenst., 1846-1849, p. 314, pl. 22, fig. 25a.

Aptychus lamellosus crassicauda Quenst., 1858, p. 596, pl. 77 , fig. 9 .

Aptychus lamellosus crassicauda Quenst., 1885, p. 590, pl. 46 , fig. 18 .

Lamellaptychus crassicauda (Quenst.), Trauth, 1938, p. 162, pl. 11, fig. 16-19.

Lamellaptychus crassicauda (Quenst.), Gasiorowski, 1962 , pl. 4, fig. 3.

Sample $367-35-5,38-39 \mathrm{~cm}$ : This species is represented by three juvenile specimens. Their specific feature is a conspicuous thickening of the ventral termination of the valve. This accumulation of calcite is associated with a partial disappearance of the lamellae over this region. The thickening at this juvenile stage can be followed weakly along the symphysal margin towards the apex. The lamellae are parallel to the lateral margin, as well as to the growth segments visible on the concave surface, and they meet the symphysis at $65^{\circ}$. The width-index attains 0.56 .

This form has been described from the Oxfordian in France (Dép. Ardèche) by Sayn and Roman (1930, p. 244), from Switzerland (Badener-Schichten, lower 
Kimmeridgian) by Moesch (1867, p. 191), and from southern Germany within the Epipeltoceras bimammatum Zone (Bruder, 1882). From the Carpathians, Gasiorowski listed it under horizon III (Gregoryceras transversarium Zone, Oxfordian).

\section{Lamellaptychus sparcilamellosus (Guembel)}

(Plate 1, Figures 8, 9)

Aptychus sparcilamellosus Guemb., 1861, p. 515.

Aptychus sparcilamellosus Guemb., Gilliéron, 1873, p. 236 , pl. 9, fig. 6 .

Aptychus sparcilamellosus Guemb., Favre, 1875, p. 50 , pl. 7 , fig. $6-9$.

Aptychi imbricati, Loriol, 1881, p. 27, pl. 7, fig. 6.

Lamellaptychus sparcilamellosus (Guemb.), Trauth, 1938 , p. 165 , pl. 11, fig. 23-27.

Lamellaptychus sparcilamellosus (Guemb.), Gasiorowski, 1962, pl. 5, fig. 2.

Samples 367-35-5, 38-39 cm and 367-35, CC: A left and a right valve were recovered. Both are small but still identifiable. This species is characterized by a welldeveloped symphysal plate, against which the lamellae bend and lean towards the ventral termination of the valve. They are widely spaced, and follow at that size the ventral margin of the valve. The width-index attains 0.52 , against 0.53 for a larger specimen figured by Favre (1875, pl. 7, fig. 9). A similar form is L. lamellosus, which, however, possesses no symphysal plate.

L. sparcilamellosus is widely distributed in the Alpine-Mediterranean facies province, where it occurs in Italy (Campana, 1904, p. 241); Germany and France in the Oxfordian transversarium and bimammatum zone (Trauth, p. 167); Switzerland (Favre, 1876, p. 50); Austria (Trauth, p. 167); Carpathians (Gasiorowski, 1962, horizon IV).

\section{Lamellaptychus murocostatus Trauth} (Plate 1, Figure 10)

Lamellaptychus murocostatus Trauth, 1938, p. 142, pl. 10, fig. 21, 22, holotype.

?Lamellaptychus murocostatus Trauth, Renz, 1972, p. 614 , pl. 3 , fig. la,b.

Sample $367-35-5,38-39 \mathrm{~cm}$ : The present right valve is characterized by its steep, wall-like lamellae, which lean against the symphysal edge, following it towards the ventral end of the valve. There is no symphysal plate developed, and this is also so on the holotype. The width-index is 0.56 , against 0.63 for the holotype. Apical angle $=107^{\circ}$, symphysal index $(\mathrm{S}: \mathrm{H})=0.90$.

The holotype of L. murocostatus is derived, according to F. Toula, who collected it, from a white Tithonian limestone from the Rote Berg near Vienna (Trauth, p. 142). The present specimen, identical with the holotype, forms part of an Oxfordian assemblage. This discrepancy in age might suggest an older age for the white limestone which furnished the holotype.

The Lamellaptychus from Sample 11-105-36-2, 34-36 $\mathrm{cm}$, determined by Renz, 1972 (p. 614) as L. murocostatus, possesses a well-developed symphysal plate, and it might therefore be connected to a different ammonite species. A new name might be introduced when a closer correlation of the well-sections is available.
From Core 35, Section 5 some additional, undetermined, poorly preserved specimens may be mentioned. If better material appears during future drilling, these might gain importance.

\section{Lamellaptychus sp. \\ (Plate 1, Figure 14)}

Sample $367-35-5,38-39 \mathrm{~cm}$. This specimen is distinguished by a considerable thickening of the circumapical region caused by deposition of a layer of calcium carbonate covering the lamellae similar to that on Punctaptychus.

\section{Lamellaptychus sp. \\ (Plate 1, Figure 13)}

Sample $367-35-5,38-39 \mathrm{~cm}$ : This thin and very fragile juvenile valve resembles Lamellaptychus hauffianus (Oppel) (1863, p. 211, pl. 56, fig. 3). The typical thickening along the external margin, however, is not developed on the present specimen, perhaps due to its juvenile stage.

\section{CONCLUSIONS}

The following aptychi could be isolated from Core 367-35:

\begin{tabular}{|c|c|c|}
\hline $35-4,147-148 \mathrm{~cm}$ & $\begin{array}{l}\text { Lamellaptychus } \\
\text { cf. thoro }\end{array}$ & Plate 1, Figures 3,4 \\
\hline $35-4,147-148 \mathrm{~cm}$ & $\begin{array}{l}\text { Lamellaptychus } \\
\text { ? lithographicus }\end{array}$ & Plate 1, Figures 7a, b \\
\hline $35-5,141-142 \mathrm{~cm}$ & $\begin{array}{l}\text { Lamellaptychus } \\
\text { cf. thoro }\end{array}$ & Plate 1, Figures 5, 6 \\
\hline $35-5, \quad 38-39 \mathrm{~cm}$ & $\begin{array}{l}\text { Lamellaptychus } \\
\text { crassicauda }\end{array}$ & Plate 1 , Figures 11,12 \\
\hline $35-5, \quad 38-39 \mathrm{~cm}$ & $\begin{array}{l}\text { Lamellaptychus } \\
\text { sparcilamellosus }\end{array}$ & Plate 1, Figure 9 \\
\hline $35-5, \quad 38-39 \mathrm{~cm}$ & $\begin{array}{l}\text { Lamellaptychus } \\
\text { murocostatus }\end{array}$ & Plate 1 , Figure 10 \\
\hline $35-5, \quad 38-39 \mathrm{~cm}$ & $\begin{array}{l}\text { Lamellaptychus } \\
\text { sp. }\end{array}$ & Plate 1. Figure 13 \\
\hline $35-5, \quad 38-39 \mathrm{~cm}$ & $\begin{array}{l}\text { Lamellaptychus } \\
\text { sp. }\end{array}$ & Plate 1, Figure 14 \\
\hline $35-5, \quad 68-69 \mathrm{~cm}$ & $\begin{array}{l}\text { Laevaptychus } \\
\text { latus seriporus }\end{array}$ & Plate 1, Figures 2a, b \\
\hline
\end{tabular}

Most of the species observed within the 1.45 -meter interval are reported from the Oxfordian as well as from the Kimmeridgian. In the Carpathians, Gasiorowski mentions them from horizons III and IV, corresponding to the late Oxfordian. Based on the informations available so far, we suggest an Oxfordian age for this assemblage.

\section{SECTION 367-34-4}

Three samples have been collected over an interval of $22 \mathrm{~cm}$. The sediment features are characteristic for the Rosso ad Aptici occurring in Italy and other places in the tethyan Upper Jurassic. Where no Radiolaria occur, the sediment consists of carbonates (50\%-65\%) and red clay. If Radiolaria are abundant the carbonate content decreases to $30 \%$. The aptychi-fauna is 
extraordinarily diversified and quite distinct from that of the underlying samples.

\section{Punctaptychus punctatus (Voltz)}

(Plate 1, Figure 16)

Punctaptychus punctatus (Voltz), Trauth, 1935, p. 315, pl. 12, fig. 1-6, cum synon.

Punctaptychus punctatus (Voltz), Renz, 1972, p. 612, pl. 1, fig. 5a-c, cum synon.

Sample 367-34-4, 64-65 cm and 34-4, 43-44 cm: Both valves were cut diagonally when sawing the core, such that only the apical regions are available. As far as we know P. punctatus is restricted to the AlpineMediterranean region, where it is widely distributed. It is a characteristic fossil indicating a Late Jurassic age.

\section{Granulaptychus planulati (Quenstedt)}

(Plate 1, Figures 15a, b)

Aptychus planulati Quenstedt, 1852, p. 382, pl. 30, fig. 10

Aptychus von Am. ulmensis Oppel, 1863, p. 261, pl. 74 , fig. 3 .

Aptychus planulati (spinulatus) Quenstedt, 1887-1888, p. 1080 , pl. 26 , fig. 2 .

Granulaptychus, Trauth, 1927, p. 213-241.

Granulaptychus planulati (Quenst.), Trauth, 1937, p. 154, pl. 11, fig. 5-11, cum synon.

Sample 367-34-4, 44-45 cm: For an accurate age determination this uncommon specimen is significant. It is embedded in a brick-red, hard limestone (carbonates $63 \%$ ). When examining the core, broken off spines appeared as shown in Plate 1, Figure 15b. The cleaning of the valve from the tough sediment was only partly successful, but nevertheless the characteristic features are recognizable. The ventral margin of this right valve is preserved. The surface shows concentric ribs from which numerous, irregularly spaced knobs and spines project. Those spines are of variable size and arranged approximately along two rows. Their tops are obtuse and well rounded.

Granulaptychus planulati has repeatedly been observed within the body chambers of Perisphinctidae, especially of Litharcoceras ulmensis (Oppel), the type fossil for the ulmensis Zone (Trauth, 1937, pl. 11, fig. 5). Those finds are from the Malm zeta in Württemberg, as well as Solnhofen in Bavaria. The importance of this fossil for a subdivision of the Jurassic interval of Site 367 is obvious. It indicates a level, which according to our present knowledge, permits a reasonable correlation with the Jurassic section of southern Germany.

The only Granulaptychus known from the Mediterranean region is G. trescorrensis Trauth $(1937$, p. 158 , p. 11, fig. 13-16) described by Meneghini (1881, p. 211, 240, pl. 31) from a red marly Late Jurassic limestone in the Lombardian Alps in the vicinity of Trescorre.

\section{Lamellaptychus pleiadensis Trauth}

(Plate 1, Figure 17)

Aptychus sp. ind, Favre, 1877, p. 70, pl. 9, fig. 2. Lamellaptychus pleiadensis Trauth, 1938, p. 164, pl. 11, fig. 22 .
Lamellaptychus pleiadensis Trauth, Gasiorowski, 1962, pl. 5, fig. 14 .

Samples $367-34-4,43-44$ and $34-4,44-45 \mathrm{~cm}$ : The important feature of these two right valves is the parallel course of the lamellae with the lateral margin and a clearly developed narrow symphysal plate at right angles to the lamellae.

L. pleiadensis is known from the lower part of the Malm delta (acanthicum-Schichten, early Kimmeridgian) from Pléiades in the Canton Fribourg in Switzerland. Gasiorowski (1962, pl. 5) quotes this species from horizons IV and V, corresponding to the early Kimmeridgian.

\section{Laevaptychus latus vermiporus Trauth}

(Plate 1, Figures 18a, b)

Laevaptychus latus Parkinson var. vermiporus Trauth, 1931 , p. 81.

Sample 367-34-4, 44-45 cm: The pores on the convex surface of this fragment display a vermiform and ramified pattern as reproduced on Plate 1, Figure 18b. After a tentative reconstruction of the valve, a widthindex of 0.74 is obtained, which is within the range for Laevaptychus latus (0.67-0.80).

This form, described but never illustrated by Trauth, is derived, like Granulaptychus planulati, from the Malm zeta of Solnhofen (middle Kimmeridgian).

\section{CONCLUSIONS}

The four species recovered from Core 34 belong to different groups and indicate that a very rich ammonite assemblage must have lived during deposition of this interval.

\begin{tabular}{|c|c|c|}
\hline $34-4,43-44 \mathrm{~cm}$ & $\begin{array}{l}\text { Punctaptychus } \\
\text { punctatus }\end{array}$ & \\
\hline $34-4,43-44 \mathrm{~cm}$ & $\begin{array}{l}\text { Lamellaptychus } \\
\text { pleiadensis }\end{array}$ & Plate 1, Figure 17 \\
\hline $34-4,44-45 \mathrm{~cm}$ & $\begin{array}{l}\text { Granulaptychus } \\
\text { planulati }\end{array}$ & Plate 1, Figures $15 \mathrm{a}, \mathrm{b}$ \\
\hline $34-4,44-45 \mathrm{~cm}$ & $\begin{array}{l}\text { Lamellaptychus } \\
\text { pleiadensis }\end{array}$ & \\
\hline $34-4,44-45 \mathrm{~cm}$ & $\begin{array}{l}\text { Laevapt. latus } \\
\text { vermiporus }\end{array}$ & Plate 1, Figures $18 \mathrm{a}, \mathrm{b}$ \\
\hline $34-4,64-65 \mathrm{~cm}$ & $\begin{array}{l}\text { Punctaptychus } \\
\text { punctatus }\end{array}$ & Plate 1, Figure 16 \\
\hline
\end{tabular}

There are 9.83 meters of sediment separating this fauna from the late Oxfordian assemblage previously discussed. An age determination is based mainly on Granulaptychus planulati and Lamellaptychus pleiadensis, which are both reported from the early Kimmeridgian. The Oxfordian-Kimmeridgian boundary is perhaps somewhere between Sample 367-35-2, $84-85 \mathrm{~cm}$ (fragments of Inoceramus in a brick-red matrix without aptychi) and Sample 367-34-4, 64-65 $\mathrm{cm}$.

\section{SECTIONS 367-31-1 AND 367-31-2; SAMPLE 367-30, CC}

The aptychi assemblage of Core $367-31$ is separated from the preceding fauna of late Kimmeridgian age by 67 meters of sediment. Only one sample of gray 
calcilutite without aptychi (Sample 367-33-2, 93-94 cm) is present from this interval. The lithology changes from the Rosso ad Aptici facies into a gray, finegrained calcilutite interspersed with abundant thin laminae and flakes of a white apparently powdery calcite. Its carbonate content varies between $48 \%$ and $52 \%$.

Most probably this sediment sequence represents the Tithonian. A correlation with Cores 33 and 34 from Site 105 in the northwestern Atlantic is suggested by the presence of typical Lamellaptychi such as L. beyrichi, L. lamellosus, and L. rectecostatus (Renz, 1972, pl. 2, 3.).

\section{Lamellaptychus aplanatus (Gilliéron)}

(Plate 1, Figures 25a,b)

Aptychus aplanatus Gilliéron, 1873, p. 238, pl. 10, fig. 4.

Lamellaptychus aplanatus (Gill.), Trauth, 1938, p. 171, pl. 12, fig. 8-10.

Lamellaptychus aplanatus (Gill.), Gasiorowski, 1962, pl. 6 , fig. $9 ;$ pl. 7 , fig. 8 .

Sample $367-31-2,2-3 \mathrm{~cm}$ and $31-2,4-5 \mathrm{~cm}$ (identical, slightly compressed specimen): On the better preserved upper surface (Figure 25a) the concave side of the left valve overlaps onto the impression of the convex side of the right valve. We observe a flat, broad, arch-like elevation (keel), beginning near the apex and following the line of the symphysis as far as the middle of the valve, from where it flattens out. Its slope towards the symphysis is considerably steeper than towards the lateral margin. The lamellae are parallel to the lateral and ventral margins and develop a very slight inflection over this elevation. They meet the symphysal edge at an acute angle (around $60^{\circ}$ ). The width-index amounts to 0.53 , and thus lies well within the limits for this form (0.44-0.58, Trauth, p. 171).

L. aplanatus has been recorded from the Neocomian of the Swiss Alps, and from Bavaria and Austria (Tithonian-Neocomian). From the Carpathians, Gasiorowski records it from horizons VI and VII, which corresponds to the Tithonian-Berriasian.

\section{Lamellaptychus theodosia rectangulus Trauth}

(Plate 1, Figures 20a, b, 21)

Aptychus beyrichi Gemmellaro, 1868-1876, p. 25, pl. 3, fig. 18 .

Lamellaptychus theodosia rectangulus Trauth, 1938, p. 187, pl. 13 , fig. 10 .

Lamellaptychus theodosia rectangulus Trauth, Gasiorowski, 1962, pl. 6, fig. 42.

Samples 367-31-1, 94-95 cm; 31-2, 2-3 cm; and 36730, CC: The course of the lamellae is parallel to the lateral and ventral margins, and they meet the symphysis at right angles. On the larger right valve of the largest pair, even a slight retroverse bending of the lamellae can be observed. The measurements are: apical angle about $102^{\circ}$, width-index of the left valve 0.52 , of the right valve 0.57 , juvenile stage 0.53 , which compares well with the data obtained by Trauth, ranging between 0.44 and 0.60 . Such individual variations of the two valves are noticeable.

This form has been reported from the late Tithonian and the Berriasian in the Austrian Alps (Trauth, p. 187), and from the Tithonian of Sicily. Gasiorowski mentions this species from the Carpathians in horizon VI (Tithonian).

\section{Lamellaptychus noricus (Winkler) (Plate 1, Figure 22)}

Aptychus noricus Winkler, 1868, p. 27, pl. 4, fig. 14. Lamellaptychus noricus (Winkler), Trauth, 1938, p. 189 , pl. 13, fig. 14,15 , cum synon.

Lamellaptychus noricus (Winkler) Gasiorowski, 1962, pl. 7, fig. 12 .

Sample 367-31-1, 94-95 cm: This form differs from L. theodosia and $\mathrm{L}$. aplanatus by the presence of a broad elevation, crossing diagonally over the valve from the apex towards the ventral margin. The course of the rather flat lying lamellae is parallel to the lateral and ventral margins. They meet the symphysal edge with angles averaging $80^{\circ}$. The lamellae cross over the elevation without inflections. The width-index of 0.64 lies slightly above the upper level, as fixed by Trauth $(0.40-0.61)$.

L. noricus is widely distributed and has been noted in the Neocomian of the Alps from France eastwards to Austria. From the Carpathians its presence has been recorded by Gasiorowski in horizon VII corresponding to the Berriasian.

Lamellaptychus indet. 1

(Plate 1, Figures 23a, b)

Sample $367-31-2,2-3 \mathrm{~cm}$ : So far this form has not been described in the literature. Apart from the destroyed, extremely thin-shelled apical region, all characteristic features are well exposed on this pair of valves. It is a slender form, having a width-index of only 0.50 . The apical angle is about $100^{\circ}$. On the convex side a pronounced keel crosses diagonally over the middle sector of the valve and meets the symphysis below the apex. It breaks abruptly against the steep lateral facet. This implies that the last four lamellae on the ventral end of the valve terminate against the steep lateral facet. On the dorsal half of the valve a shallow depression is developed, which causes a distinct indentation along the lateral margin. Over the keel no noticeable inflection of the lamellae occurs. The symphysis is met by the lamellae at right angles (drawing Plate 1, Figure 23b).

Annotation: A closely related adult and best preserved specimen has been recovered from Sample 43-387-49-4, 104-105 cm from the western Bermuda Rise. It has been named Lamellaptychus bermudensis.

\section{Lamellaptychus indet. 2 \\ (Plate 1, Figures 24a, c)}

Section 367-31-2, 4-5 cm: Only the cast of the convex side and a few fragments of the valve are preserved. A reconstruction has been attempted (Plate 1, Figure $24 \mathrm{~b})$. The outstanding feature is a very pronounced keel, which begins near the symphysis just above the apex, and diagonally crosses over the valve to reach the lateral margin just below its turning point into the ventral margin. Towards the symphysis the keel flattens gently; towards the lateral margin, however, it falls off vertically and seems even to be slightly overturned at its base. Along the vertical slope the lamellae form two 
acute-angled bends, which gradually turn into a normal inflection towards the apex where the keel gradually gets less steep. On the flat slope towards the symphysal edge the lamellae display broad curves, which slightly recurve in the direction of the apex.

Sample 367-30, CC consists of a hard, unbedded, tough, white limestone, containing ammonites but few aptychi. In a thin section abundant calcified Radiolaria can be recognized. The ammonites recovered are poorly preserved and specifically indeterminable. They belong to the Families Phylloceratidae (1 specimen) and Haploceratidae (6 specimens). The Phylloceratid (Plate 2, Figure 9) shows a fine striation without constrictions visible, and it might represent a Hypophylloceras. The Haploceratid (Plate 2, Figure 8) could be a Haploceras. One of the two aptychi found is a small

\section{Lamellaptychus cf. theodosia (Deshayes) (Plate 1, Figure 19)}

Aptychus theodosia Deshayes in Verneuil et Deshayes, 1838, p. 32, pl. 6, fig. 6 .

Aptychus von Am. asterianus, Gilliéron, 1873, p. 229, 240 , pl. 10, fig. 1.

Lamellaptychus theodosia (Desh.), Trauth, 1938, p. 185 , fig. 8,9 .

Lamellaptychus theodosia (Desh.), Gasiorowski, 1962, pl. 6, fig. 41-43.

Sample $367-30$, CC: This form is poorly represented by a juvenile pair of valves. The lamellae follow the lateral and ventral margins and cross straight over the broadly arched convex surface. After reconstruction of the missing ventral end, a width-index of 0.55 results. According to Trauth the index varies between 0.40 and 0.56 for this species.

L. theodosia has been recorded in the upper Malm and the Berriasian in the Alpine-Mediterranean province, especially in France, Switzerland, Austria, and the Krimean Peninsula. From the Carpathians Gasiorowski listed it from the Tithonian (horizon VI), together with the "variety" rectangulus.

\section{CONCLUSIONS}

The interval reaching a thickness of only $60 \mathrm{~cm}$ is conspicuously rich in aptychi as six species could be recovered.

\begin{tabular}{|c|c|c|}
\hline $30, \mathrm{CC}$ & $\begin{array}{l}\text { L. theodosia } \\
\text { rectangulus }\end{array}$ & \\
\hline $30, \mathrm{CC}$ & L. cf. theodosia & Plate 1, Figure 19 \\
\hline $31-1,94-95 \mathrm{~cm}$ & L. noricus & Plate 1, Figure 22 \\
\hline $31-1,94-95 \mathrm{~cm}$ & $\begin{array}{l}\text { L. theodosia } \\
\text { rectangulus }\end{array}$ & Plate 1, Figures $20 \mathrm{a}, \mathrm{b}$ \\
\hline $31-2, \quad 2-3 \mathrm{~cm}$ & L. Indet. 1 & Plate 1, Figures 23a, b \\
\hline $31-2, \quad 2-3 \mathrm{~cm}$ & $\begin{array}{l}\text { L. theodosia } \\
\text { rectangulus }\end{array}$ & Plate 1, Figure 21 \\
\hline $31-2, \quad 4-5 \mathrm{~cm}$ & L. indet. 2 & Plate 1, Figures 24a-c \\
\hline $31-2,4-5 \mathrm{~cm}$ & L. aplanatus & Plate 1, Figures 25a, b \\
\hline
\end{tabular}

During this period the initial stages towards a retroverse lamellae-pattern began to develop. Based on the available material, we place this assemblage within the transition zone from the Tithonian to the Berriasian.

\section{SECTIONS 367-28-1 AND 367-28-2}

This interval is separated from the preceding samples, which we assumed to be within the transition zone from Late Jurassic to Early Cretaceous, by a sediment column of 79.83 meters. The present samples consist of gray calcilutite with similar flakes and patches of white powdery calcite as observed on samples from Core 367-31. The carbonate-content of some samples examined remains above $50 \%$. The residue is a dark gray clay, rich in small pyrite octahedra.

\section{Lamellaptychus didayi (Coquand) \\ (Plate 1, Figures 26a-c)}

Aptychus didayi Coquand, 1841, p. 389, pl. 1, fig. 10. Trigonellites didayi Coqu., Ooster, 1857, p. 28, pl. 7, fig. 8.

Aptychus didayi Coqu., Pictet and Loriol, 1858, p. 46, pl. 10, fig. 1.

Aptychus didayi Coqu., Winkler, 1868, p. 28, pl. 4, fig. 16.

Lammellaptychus didayi (Coqu.), Trauth, 1938, p. 198 , pl. 14, fig. 3,4 .

Lammellaptychus didayi (Coqu.), Gasiorowski, 1962, pl. 8 , fig. 9 .

Sample 367-28-2, 66-67 cm: The ventral half of the two valves has been cut off when splitting the core. The left valve overlaps on the symphysal half of the right valve (Figure 26a), and it shows the beginning of a broad and flat elevation. On its steeper slope towards the symphysis we observe the beginning of the retroverse turning of the lamellae (Figure 26c). A weak inflection of the lamellae is present over the elevation.

According to the literature $\mathrm{L}$. didayi is a widely distributed species (Trauth, 1938, p. 200). It has been reported within the Alpine-Mediterranean province, mainly from Spain (Kilian, 1907-1913), southern France, and the Swiss Alps (Ooster, 1857), the Bavarian Alps, Austria, and Italy. From the Carpathians, Gasiorowski mentions this form from horizon VIII representing the Valanginian and Hauterivian. Lacoste (1934, p. 272) noted its presence in Morocco.

\section{Lamellaptychus aff. herthae (Winkler)}

(Plate 1, Figures 31-33)

Aptychus herthae Winkler, 1868, p. 28, pl. 4, fig. 12. Lamellaptychus herthae (Winkler), Trauth, 1938, p. 178, pl. 12 , fig. 22

Lamellaptychus herthae (Winkler), Gasiorowski, 1962, pl. 7 , fig. 2 .

Samples $367-28-2,66-67 \mathrm{~cm}$ and $28-2,60-61 \mathrm{~cm}$ : Four identical small specimens could be obtained from both samples, indicating an abundant occurrence at this level. Outstanding is a keel with steep flanks on both sides, extending diagonally over the valve from the apex to the lateral margin. On the dorsal half of the valve a very shallow depression is developed, which implies a slight concave indentation of the lateral margin. The steep lateral facet flattens out abruptly at its base, filling the space resulting from the indentation 
(pointed area on Plate 1, Figure 32b). Over the keel the lamellae form acute inflections and meet the symphysal edge at angles of about $70^{\circ}$, compared with $40^{\circ}-60^{\circ}$ on a typical L. herthae.

This species is known from Tithonian-Neocomian limestones in the Austrian and Bavarian Alps (Trauth, p. 179). In the Carpathians it occurs in the Berriasian (horizon VII of Gasiorowski).

\section{Lamellaptychus seranonis (Coquand)}

(Plate 1, Figures 28, 29)

Aptychus seranonis Coquand, 1841, p. 390, pl. 9, fig. 13.

Aptychus seranonis Coqu., Pictet and Loriol, 1858, p. 48 , pl. 11, fig. 1, 2 .

Lamellaptychus seranonis (Coqu.), Trauth, 1938, p. 193, pl. 13, fig. 27-29.

Lamellaptychus seranonis (Coqu.), Gasiorowski, 1962, pl. 8, fig. 13, 14.

Lamellaptychus seranonis (Coqu.), Renz, 1972, p. 615, pl. 3, fig. 4,5 .

Samples 367-28-1, 58-59 $\mathrm{cm}$ and 28-1, 60-61 cm: These two pairs of valves are comparable with specimens figured by Pictet and Loriol (1858, p. 48) from the Neocomian of the French Alps (Voirons) and reproduced by Trauth (pl. 13, fig. 27, 28). They also are largely identical with L. seranonis described from the western North Atlantic (Renz, 1972, p. 615, fig. 4, $5)$. The width-index amounts to 0.52 for the larger specimen and 0.50 for the smaller one. The respective apical angles are about $90^{\circ}$ to $100^{\circ}$. A very shallow depression on the marginal flank of the keel is recognizable.

\section{Lamellaptychus ? seranonis (Coquand)}

(Plate 1, Figure 30)

Sample 367-28-1, 60-61 cm: Whether this juvenile pair of valves should be grouped with $\mathrm{L}$. seranonis is questionable. Based on its slender outline (width-index 0.36 ) it probably belonged to a quite different ammonite species. A peculiar feature is the elevation which covers the dorsal half of the valve. It rises abruptly along a line crossing the valve diagonally. The laminae at that size run straight over this elevation. Due to the juvenile stage of this specimen a new name is not introduced.

\begin{tabular}{lll}
\hline $28-1,58-59 \mathrm{~cm}$ & $\begin{array}{l}\text { Lamellaptychus } \\
\text { seranonis }\end{array}$ & Plate 1, Figure 28 \\
$28-1,60-61 \mathrm{~cm}$ & $\begin{array}{l}\text { Lamellaptychus } \\
\text { seranonis }\end{array}$ & Plate 1, Figure 29 \\
$28-1,60-61 \mathrm{~cm}$ & $\begin{array}{l}\text { Lamellaptychus } \\
\text { aff. herthae }\end{array}$ & Plate 1, Figure 32 \\
$28-1,60-61 \mathrm{~cm}$ & $\begin{array}{l}\text { Lamellaptychus } \\
\text { aff. seranonis }\end{array}$ & Plate 1, Figures 27a, b \\
$28-1,60-61 \mathrm{~cm}$ & $\begin{array}{l}\text { Lamellaptychus } \\
\text { ? seranonis }\end{array}$ & Plate 1, Figure 20 \\
$28-2,66-67 \mathrm{~cm}$ & $\begin{array}{l}\text { Lamellaptychus } \\
\text { didayi }\end{array}$ & Plate 1, Figures 26a-c \\
$28-2,66-67 \mathrm{~cm}$ & $\begin{array}{l}\text { Lamellaptychus } \\
\text { aff. herthae }\end{array}$ & Plate 1, Figures 31, 33 \\
\hline
\end{tabular}

\section{CONCLUSIONS}

For a reliable age determination this small fauna is evidently not sufficient. The presence of $\mathrm{L}$. didayi and representatives of the seranonis group suggests an Early Cretaceous age, probably Valanginian.

\section{SECTION 367-27-3 AND SECTIONS 367-26-1 TO $367-26-4$}

This interval reaches a thickness of 25 meters, and it is separated from the previous samples by a gap of 23 meters. The sediment is a similar gray, rather uniform calcilutite (carbonate content $40 \%-48 \%$ ) as composing the samples from Core 28 below. A fish-vertebra (diameter $4 \mathrm{~mm}$ ) is preserved in Sample 367-27-3, 94-95 $\mathrm{cm}$.

\section{Group of Lamellaptychus angulocostatus (Peters)}

The Lamellaptychi observed within this interval are all distinguished by a retroverse lamellae pattern as characteristic for L. angulocostatus. Nevertheless they display such considerable variations that we may assume that different ammonite species are involved.

\section{Lamellaptychus angulocostatus (Peters)}

Lamellaptychus angulocostatus (Peters), Trauth, 1938, p. 204 , pl. 14, fig. 12, 13.

Lamellaptychus angulocostatus (Peters), Gasiorowski, 1962, pl. 8, fig. 1, 4 .

Lamellaptychus angulocostatus (Peters), Renz, 1972, p. 616 , pl. 4 , fig. 1a, b.

\section{SAMPLE 367-27-3, 94-95 CM}

(Plate 1, Figure 34)

The pronounced elevation covering the entire dorsal half of the valve shows a shallow depression towards the lateral margin, which causes a slight indentation, as on L. seranonis. The lamellae cross straight over this elevation. On the left valve they display a typical "angulocostatus" pattern, whereas on the right valve they rather seem to resemble L. seranonis. The outlines of the two valves are noticeably different. The widthindex of the right valve is 0.49 against 0.40 for the left one.

\section{SAMPLE 367-27-3, 25-26 CM}

(Plate 1, Figure 35)

The lamellae pattern is typical for L. angulocostatus. The two valves, as far as preserved are very even and the lamellae widely spaced.

\section{SAMPLE 367-26-3, 58-59 CM \\ (Plate 2, Figure 2)}

Aptychus angulocostatus Peters, Pictet et Loriol, 1858, pl. 10, fig. 3., proposed lectotype.

This specimen closely resembles the specimen figured by Pictet and Loriol (1858) from Hivernages in the Montagne des Voirons.

\section{SAMPLE 367-26-4, 58-59 CM \\ (Plate 2, Figure 1)}

Aptychus angulocostatus Peters, Pictet and Loriol, 1858 , p. 46 , pl. 10 , fig. 8 a-d. 
This specimen differs from the proposed lectotype by its broad elevation following the symphysis from the apex to the ventral margin. The retroverse turning of the lamellae occurs along the steep slope following the symphysis. This form is best comparable with Pictet's and Loriol's drawing (1858, pl. 10, fig. 8) of another specimen from the Montagne des Voirons near Geneva.

\section{SECTION 367-26-2, 67-68 CM}

\section{Lamellaptychus angulocostatus aff, cristobalensis (O'Connell)}

(Plate 2, Figure 3)

Lamellaptychus angulocostatus cristobalensis ( $\mathrm{O}^{\prime} \mathrm{Con}$ nell), Imlay, 1942, p. 1460, pl. 11, fig. 2.

The ventral part of a large left valve is preserved. The acute angled lamellae turn rounded towards the ventral end of the valve. An approach to the variety cristobalensis (O'Connell) from the Viñales Limestone in Cuba might be suggested (Imlay, 1942, pl. 11, fig. 2). Similar valves have been described from the northwestern Atlantic as L. atlanticus Hennig (Renz, 1972, p. 617 , pl. 4, fig. 2a,b, 3, 4, Leg 11, Site 105).

A juvenile pair of valves appeared within this sample (Plate 2, Figure 4). Its width-index reaches 0.54 , and the acute angled lamellae are well developed at that size (compare Pictet and Loriol, 1858, pl. 10, fig. 11, 12).

\section{Lamellaptychus angulocostatus fractocostatus Trauth} (Plate 2, Figures 5-7)

Lamellaptychus angulocostatus var. fractocostata Trauth, 1938, p. 208, pl. 14, fig. 17.

Lamellaptychus angulocostatus fractocostatus, Gasiorowski, 1962, pl. 8, fig. 2.

Samples 367-26-1, 69-70 cm and 26-1, $41 \mathrm{~cm}$ : A wellpreserved pair of valves and a left valve representing the juvenile stage are available. A well-marked keel crosses diagonally over the valve from above the apex to the ventral margin. It declines moderately steep towards the symphysal edge, and more steeply towards the lateral margin. Along this steeper slope the lamellae form the characteristic retroverse angles. The widthindex is 0.50 , compared with 0.43 on the specimens figured by Trauth.

This form is known from the Neocomian of Gardenaza in northern Italy, and from the Carpathians within horizon VIII of Gasiorowski indicating a Hauterivian age.

\section{CONCLUSIONS}

Six samples which all furnished determinable aptychi are available.

\begin{tabular}{|c|c|c|}
\hline $26-1,41 \mathrm{~cm}$ & $\begin{array}{l}\text { L. angulocostatus } \\
\text { fractocostatus }\end{array}$ & Plate 2, Figure 7 \\
\hline $26-1,69-70 \mathrm{~cm}$ & $\begin{array}{l}\text { L. angulocostatus } \\
\text { fractocostatus }\end{array}$ & Plate 2, Figures 5, 6 \\
\hline $26-2,67-68 \mathrm{~cm}$ & $\begin{array}{l}\text { L. angulocostatus } \\
\text { aff. cristobalensis }\end{array}$ & Plate 2, Figure 3 \\
\hline $26-3,58-59 \mathrm{~cm}$ & L. angulocostatus & Plate 2, Figure 2 \\
\hline $26-4,58-59 \mathrm{~cm}$ & L. angulocostatus & Plate 2, Figure 1 \\
\hline $27-3,25-26 \mathrm{~cm}$ & L. angulocostatus & Plate 1, Figure 36 \\
\hline $27-3,94-95 \mathrm{~cm}$ & L. angulocostatus & Plate 1, Figure 35 \\
\hline
\end{tabular}

This interval is dominated by Lamellaptychus angulocostatus in several varieties. In the Carpathians, L. angulocostatus occurs within horizon VIII of Gasiorowski, corresponding to the Hauterivian. Also on the Montagne des Voirons (near Geneva) a Hauterivian ammonite fauna accompanies L. angulocostatus.

\section{ACKNOWLEDGMENTS}

This paper has been prepared at the Museum of Natural history in Basel, Switzerland. The author wishes to thank Yves Lancelot, Co-Chief Scientist of Leg 41, for having assembled the aptychi collection from Site 367. I am especially grateful to J.B. Saunders for reading the manuscript critically. His numerous valuable suggestions are incorporated in the text. The photographic work has been carried out by W. Suter of the Museum.

\section{REFERENCES}

Campana, D., 1904. Faunula del Giura superiore di Collalto di Solagna (Bassano): Soc. Geol. Ital. Bull., v. 23, p. 239269.

Castillo, A. y Aguilera, J.G., 1895. Fauna fossil de la Sierra de Catorce, San Luis Potosí: Bol. Com. Geol. Mexico, v. 1 , p. 55 .

Coquand, M., 1841. Mémoire sur les Aptychus: Soc. Géol. France Bull., v. 12, p. 376-391.

Deshayes, P., in Verneuil, E., 1838. Mémoire géologique sur la Crimée suivi d'observations sur les fossiles de cette péninsule: Mém. Soc. Géol. France, v. 3, p. 31-32.

Favre, E., 1875. Description des fossiles du terrain jurassique de la Montagne des Voirons (Savoie): Mém. Soc. Paléontol. Suisse, v. 2, p. 77.

1876. Description des fossiles du terrain Oxfordien des Alpes Fribourgeoises: Mém. Soc. Paléontol. Suisse, v. 3, p. 75.

1877. La zone à Ammonites acanthicus dans les Alpes de la Suisse et dans la Savoie: Mém. Soc. Paléontol. Suisse, v. 4 , p. 113.

1880. Description des fossiles des conches tithoniques des Alpes Fribourgeoises: Mém. Soc. Paléontol. Suisse, v. 6, p. 74.

Gasiorowski, S.M., 1962. Aptychi from the Dogger, Malm and Neocomian in the Western Carpathians and their stratigraphical value: Studia Geol. Polonica, v. 10, p. 144.

Gilliéron, V., 1873. Aperçu géologique sur les Alpes de Fribourg en général et description spéciale du Monsalvens: Mat. Carte Géol. Suisse, v. 12, p. 273.

Guembel, C.W., 1861. Geognostische Beschreibung des bayerischen Alpengebietes und seines Vorlandes: Gotha, v. 1, p. 515 .

Imlay, R.W., 1942. Late Jurassic fossils from Cuba and their economic significance: Geol. Soc. Am. Bull., v. 53, p. 1417-1478.

Lacoste, J., 1934. Etudes géologiques dans le Rif méridional: Notes Mém. Serv. Géol. Maroc, v. 1, p. 463.

Loriol, P., 1881. Monographie paléontologique des couches de la zone à Ammonites tenuilobatus (Badener-Schichten) d'Oberbuchsitten et de Wangen (Soleure): Mém. Soc. Paléontol. Suisse, v. 17, p. 60.

Moesch, C., 1867. Geologische Beschreibung des AargauerJura und der nördlichen Gebiete des Kantons Zürich: Reitr. Geol. Karte Schweiz, v. 4, p. 319.

Ooster, W.A., 1857. Catalogue des céphalopodes fossiles des Alpes suisses avec la description et les figures des espéces remarquables: Part 1, p. 32.

Oppel, A., 1863. Ueber jurassische Cephalopoden: Palaeontol. Mitt. Bayer. Staates, p. 163-266. 
Pictet, F.J. and Loriol, P., 1858. Description des fossiles contenus dans les terrains néocomiens des Voirons: Mat. Paléontol. Suisse, 2 sér., p. 64.

Quenstedt, F.A., 1846-1849. Petrefactenkunde Deutschlands: Die Cephadopoden. Túbingen, p. 580.

1858. Der Jura: Tübingen, p. 842.

1883-1888. Die Ammoniten des schwäbischen Jura: Stuttgart, p. 1140.

Renz, O., 1972. Aptychi (Ammonoidea) from the upper Jurassic and lower Cretaceous of the western North Atlantic (Site 105, Leg 11, DSDP). In Hollister, C.D., Ewing, J.I., et al., Initial Reports of the Deep Sea Drilling Project, Volume 11: Washington (U.S. Government Printing Office), p. 607-629.

1974. A dwarf fauna of upper Jurassic age in the western Atlantic. DSDP, Leg 11, Site 99A: Verh. Natf. Ges. Basel, v. 84 , p. $510-520$.

Sayn, G. and Roman, F., 1930. Monographie stratigraphique et paléontologique du Jurassique moyen de la Voult-sur-Rhône: Trav. Lab. Géol. Fac. Sci. Lyon, fasc. 14 , p. 244.

Trauth, F., 1931. Aptychenstudien VI-VII: Ann. Nathist. Mus. Wien., v. 45, p. 17-136.

1935. Die Punctaptychi des Oberjura und der Unterkriede: Ib. Geol. Bundesanst., v. 85, p. 309-332. , 1937. Die Praestriaptychi und Granulaptychi des Oberjura und der Unterkreide: Palaeontol. Z., v. 19, p. $134-162$.
1938. Die Lamellaptychi des Oberjura und der Unterkreide: Palaeontographica, Abt. A., v. 88, p. 115229.

Winkler, G.G., 1868. Versteinerungen aus dem bayerischen Alpengebiet mit geognostischen Erläuterungen. 1. Die Neocomformation des Urschlauerachentales bei Traunstein mit Rücksicht aur ihre Grenzschicht: München.

\section{APPENDIX}

A peculiar sedimentary feature occurs in Sample 367-35-5, 38-39 $\mathrm{cm}$. Scanning electron micrographs illustrate this phenomenon, which has possibly also been seen by other observers. An alternation of very thin layers of calcilutite with equally thin layers of calcite is visible (pl. 2, fig. 14). The calcite layers (or plates) display a characteristic polygonal pattern, best comparable to desiccation or shrinkage cracks developing on drying clay surfaces (pl. 2, fig. 15). The upper surface of the polygonal calcite bodies is irregularly deeply dentated (pl. 2, fig. 16). This dentation suggests that diagenetic processes, perhaps some form of solution, may be responsible for this surface appearance. We observe that the tops of the dentation are projected over the rim of the coccoliths, what suggests that the deposition of the coccoliths on the calcite surface occurred before the formation of the dentation. An impression of a coccolith on the calcite surface (right half of the photograph fig. 16) also points into this direction. On the other hand a biogenetic origin cannot be fully excluded, as intact coccoliths unaffected by diagenetic solution, were deposited on the surface of the calcite polygons (pl. 2 fig. 17). 



\section{PLATE 1}

Figure 1 Sample $36-2,72-73 \mathrm{~cm}$, Oxfordian.

1a. Laevaptychus mexicanus (Castillo y Aquilera). $1.5 \times$.

1b. Convex surface showing widely spaced pores. $6 \times$.

Figures 2-14 Core 35, Sections 4, 5, late Oxfordian.

2a. Section 5, 68-69 cm: Laevaptychus latus seriporus Trauth. $1.5 \times$.

2b. Convex surface showing the arrangement of the pores. $6 \times$.

3. Section 4, 147-148 cm: Lamellaptychus cf. thoro (Oppel), concave side. $6 \times$.

4. Section 4, 147-148 cm: Lamellaptychus cf. thoro (Oppel), convex side. 6×.

5. Section 5, 141-142 cm: Lamellaptychus cf. thoro (Oppel), convex side. $6 \times$.

6. Section 5, 141-142 cm: Lamellaptychus cf. thoro (Oppel), convex side. 6X.

7a. Section 4, 147-148 cm: Lamellaptychus ? lithographicus (Oppel), convex side. $3 \times$.

7b. Section 4, 147-148 cm: Lamellaptychus ? lithographicus (Oppel), concave side, impression. $3 \times$.

8. Sample 35, CC: Lamellaptychus sparcilamellosus (Guembel). 3X.

9. Section 5, 38-39 cm: Lamellaptychus sparcilamellosus (Guembel). $3 \times$.

10. Section 5, 38-39 cm: Lamellaptychus murocostatus Trauth. $3 \times$.

11. Section 5, 38-39 cm: Lamellaptychus crassicauda (Quenstedt). 6×.

12. Section 5, 38-39 cm: Lamellaptychus crassicauda (Quenstedt), reconstruction. $6 \times$.

13. Section 5, 38-39 cm: Lamellaptychus sp. $6 \times$.

14. Section 5, 38-39 cm: Lamellaptychus sp. $6 \times$.

Figures 15-18 Core 34, Section 4, Kimmeridgian.

15a. Section 4, 44-45 cm: Granulaptychus planulati (Quenstedt). $1.5 \times$.

15b. Impression of the convex side showing broken off spines. $3 \times$.

16. Section 4, 64-65 cm: Punctaptychus punctatus (Voltz). $3 \times$.

17. Section 4, 43-44 cm: Lamellaptychus pleiadensis Trauth. $3 \times$.

18a. Section 4, 44-45 cm: Laevaptychus latus vermiporus Trauth. $1.5 \times$.

18b. Convex surface with vermiform pores. $6 \times$.

Figures 19-25 Core 31, Sections 1, 2, late Tithonian to Berriasian.

19. Sample 30, CC: Lamellaptychus cf. theodosia (Deshayes). $6 \times$.

20a. Section 1, 94-95 cm: Lamellaptychus theodosia rectangulus Trauth. $3 \times$.

20b. Section 1, 94-95 cm) Lamellaptychus theodosia rectangulus, juvenile stage. $3 \times$.

21. Section 2, $2-3 \mathrm{~cm}$ : Lamellaptychus theodosia rectangulus Trauth. $3 \times$.

22. Section 1, 94-95 cm: Lamellaptychus noricus (Winkler). $3 \times$.

23a. Section 2, 2-3 cm: Lamellaptychus indet. 1. 3X.

23b. Reconstructed left valve. $3 \times$.

24a. Section 2, 4-5 cm: Lamellaptychus indet. 2, impression. 1.5 $\times$.

24b. Reconstructed right valve. $1.5 \times$.

24c. Fragment of the right valve. $1.5 \times$.

25a. Section 2, 2-3 cm: Lamellaptychus aplanatus (Gilliéron). 1.5.

25b. Section 2, 4-5 cm: Lamellaptychus aplanatus (Gilliéron), opposite side. 1.5 $\times$.

Figures 26-33 Core 28, Sections 1, 2, Valanginian.

26a. Section 2, 66-67 cm: Lamellaptychus didayi (Coquand), convex surface. $1.5 \times$.

26b. Impression. $1.5 \times$.

26c. Reconstruction of the left valve. $1.5 \times$.

27a. Section 1, 60-61 cm: Lamellaptychus aff. seranonis (Coquand), impression. $1.5 \times$.

27b. Fragments of both valves. $1.5 \times$.

28. Section 1, 58-59 cm: Lamellaptychus seranonis (Coquand). $3 \times$.

29. Section 1, 60-61 cm: Lamellaptychus seranonis (Coquand). $3 \times$.

30. Section 1, 60-61 cm: Lamellaptychus ? seranonis (Coquand). $3 \times$.

31. Section 2, 66-67 cm: Lamellaptychus aff. herthae Winkler). $3 \times$.

32a. Section 1, 60-61 cm: Lamellaptychus aff. herthae (Winkler). 3X.

32b. Tentative reconstruction. $3 \times$.

33. Section 2, 66-67 cm: Lamellaptychus aff. herthae (Winkler). $3 \times$.

Figures 34, 35 Core 27, Section 3, Hauterivian.

34. Section 3, 94-95 cm: Lamellaptychus angulocostatus (Peters). $3 \times$.

35. Section $3,25-26 \mathrm{~cm}$ ) Lamellaptychus angulocostatus (Peters). $3 \times$. 
PLATE 1
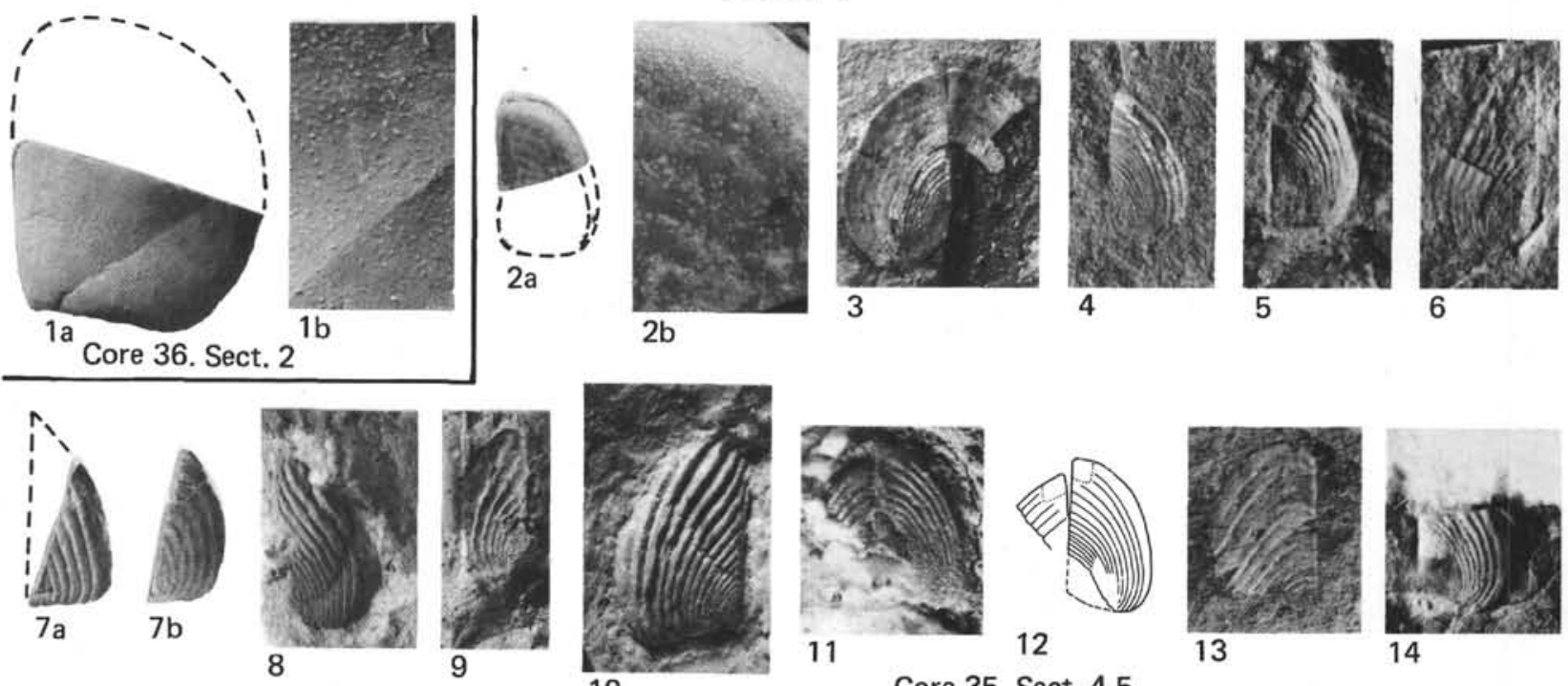

12
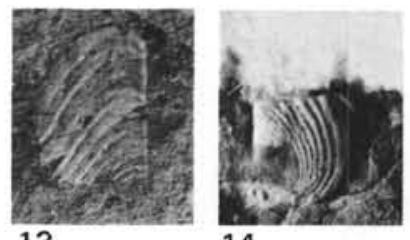

Core 35 , Sect. 4,5

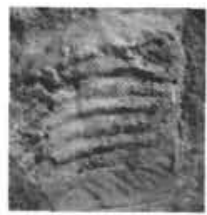

$15 a$

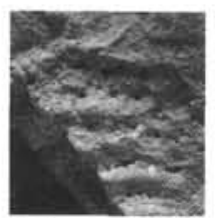

$15 b$

Core 34. Sect. 4

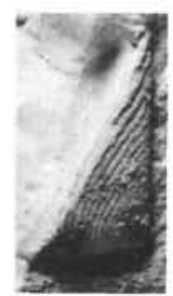

16

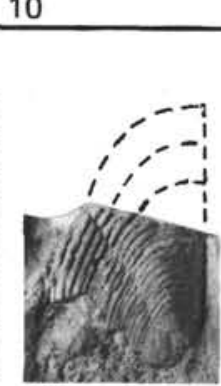

17

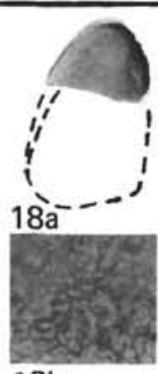

$18 b$
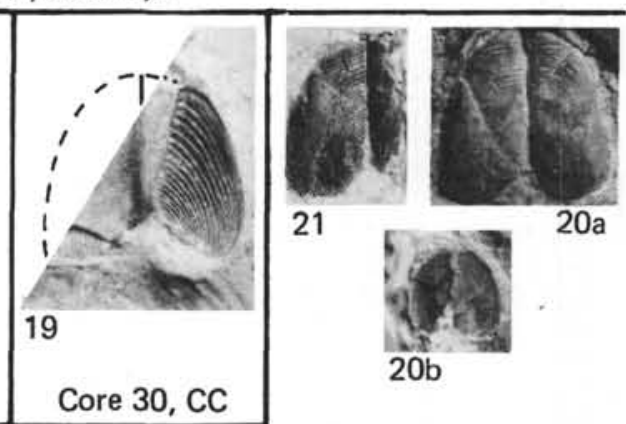

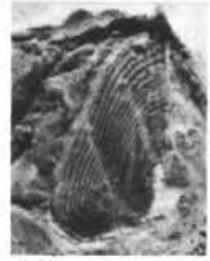

22

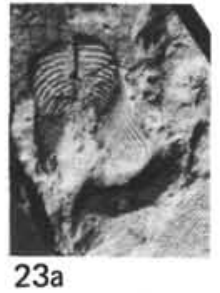

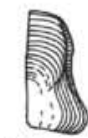

$23 b$

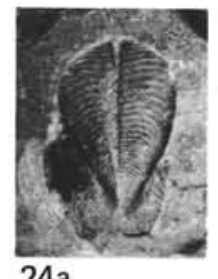

Core 31, Sect. 2
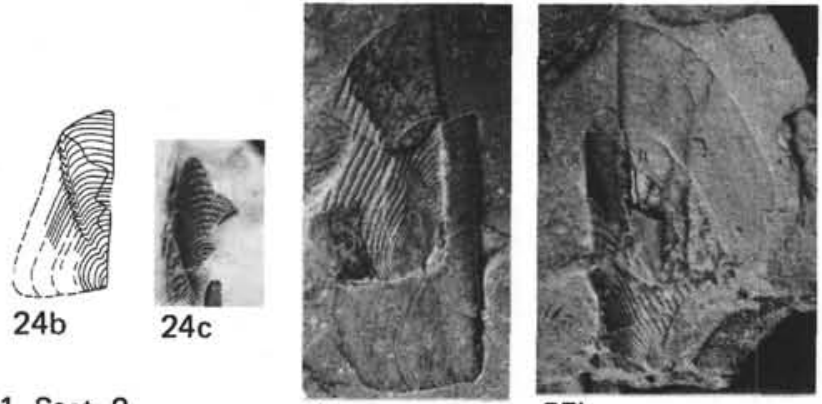

$25 b$
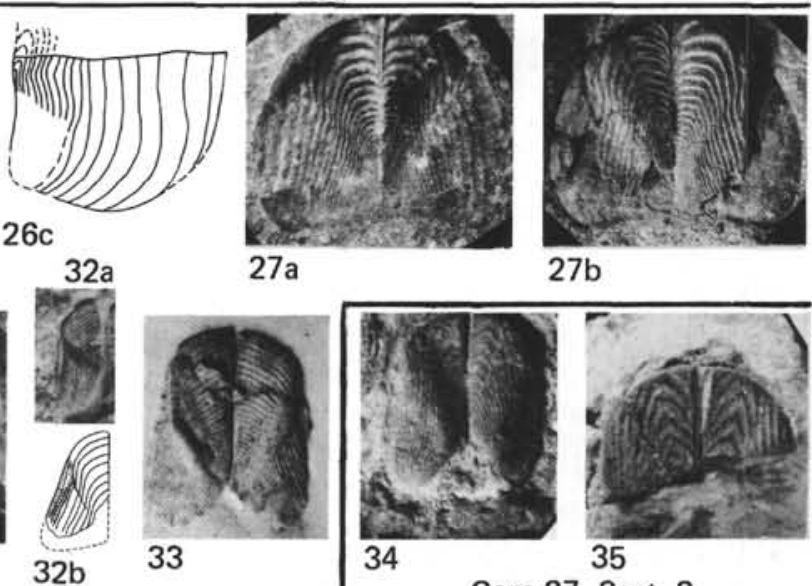

$27 b$

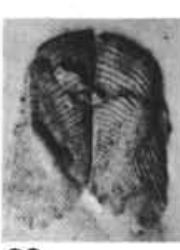

33

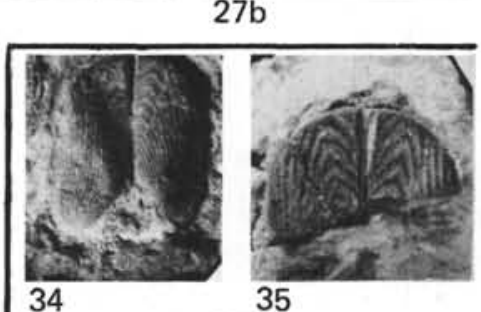

Core 27. Sect. 3

Core 28 , Sect. 1

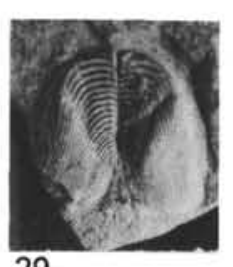

30
31

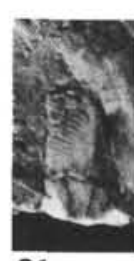

32 


\section{PLATE 2}

Figures 1-7 Core 26, Sections 1-4, Hauterivian.

1. Section 4, 58-59 cm: Lamellaptychus angulocostatus (Peters) $1.5 \times$.

2. Section $3,58-59 \mathrm{~cm}$ : Lamellaptychus angulocostatus (Peters). 1.5 .

3. Section 2, 67-68 cm: Lamellaptychus angulocostatus cristobalensis (O'Connell). 1.5X.

4. Section 2, 67-68 cm: Lamellaptychus angulocostatus (Peters). $3 \times$.

5. Section $1,69-70 \mathrm{~cm}$ : Lamellaptychus angulocostatus fractocostatus Trauth. $3 \times$.

6. Section 1, 69-70 cm: Lamellaptychus angulocostatus fractocostatus Trauth. $1.5 \times$.

7. Section 1, $41 \mathrm{~cm}$ : Lamellaptychus angulocostatus fractocostatus Trauth. 1.5X.

Figures 8,9 Cephalopoda.

8. Sample 30, CC: Haploceras sp. 1.5X.

9. Sample 30, CC: ? Hypophylloceras. 1.5×.

Figures 10-13 Rhyncholites.

10. Sample 35, CC: Gonatocheilus sp. 3×.

11. Sample 35, CC: Rhynchoteuthis sp.

12, 13. Sample $36-2,72-73 \mathrm{~cm}$ : Problematic jaw parts of cephalopods. $6 \times$.

Figures 14-17 Sedimentary features observed in Sample 35-5, 38$39 \mathrm{~cm}$.

14. Small layers of white calcite displaying a polygonal texture. $120 \times$.

15. Calcite plates alternating successively with very thin micritic sediment layers. $240 \times$.

16. The surface of the individual calcite polygons is deeply dentated. On the right half of the photograph the impression of a coccolith is visible. $600 \times$.

17. Coccolith deposited on the surface of calcite polygons. The calcite overlaps on the rim of a coccolith. $2400 \times$. 
PLATE 2

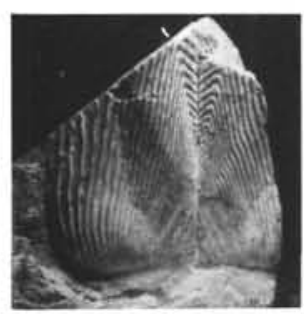

1

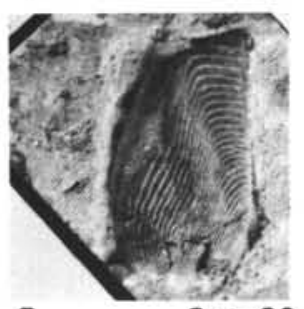

5

Core 26, Sect. $1-4$

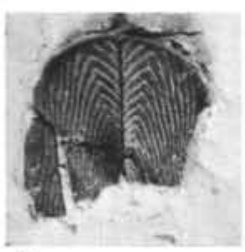

2

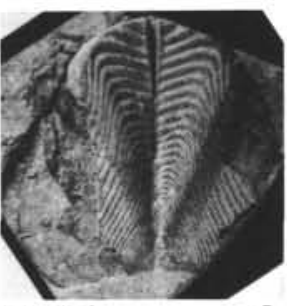

6

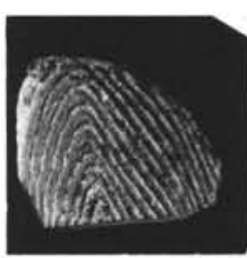

3

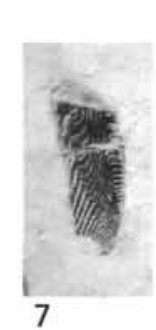

7

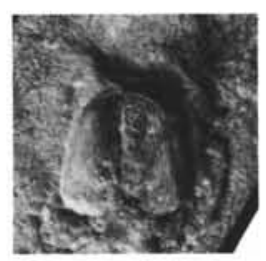

4

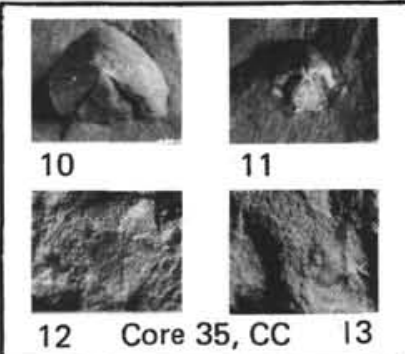

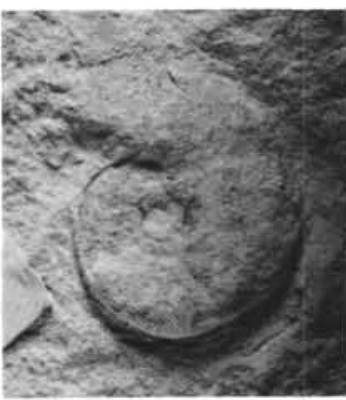

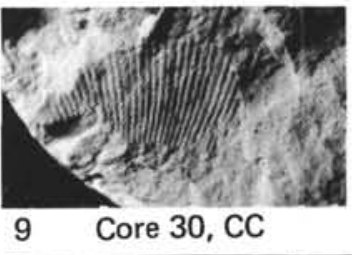

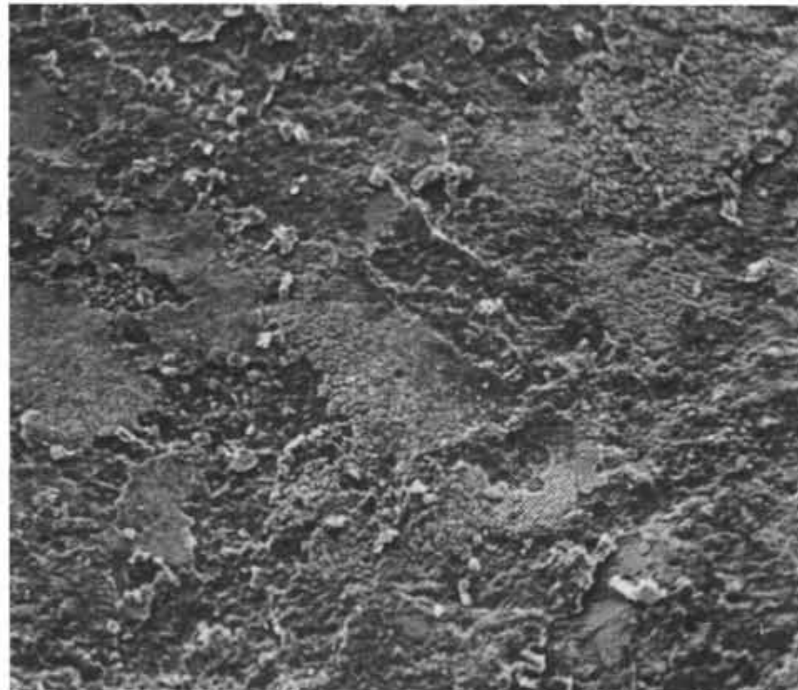

14

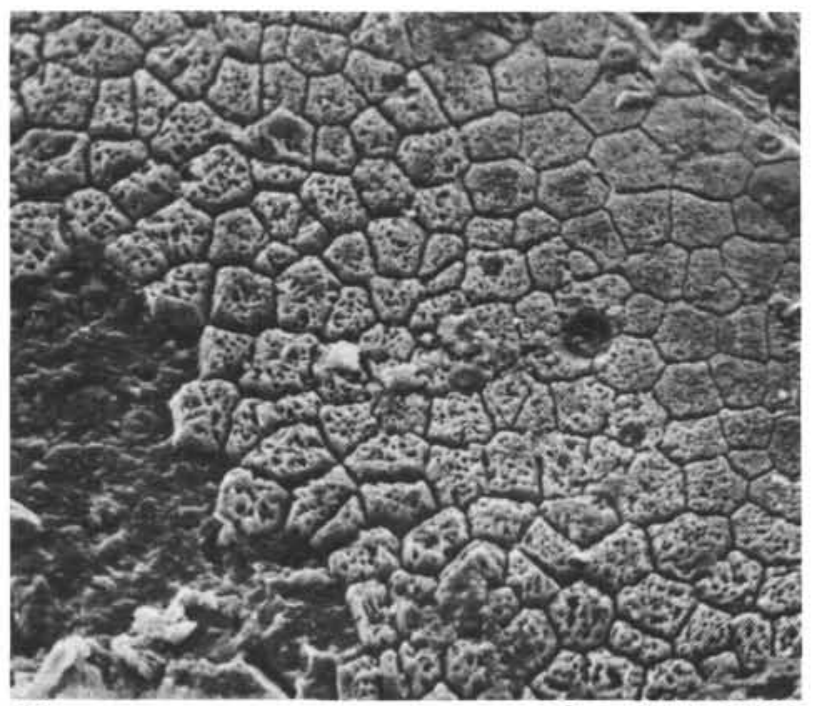

Core 35-5, 38-39

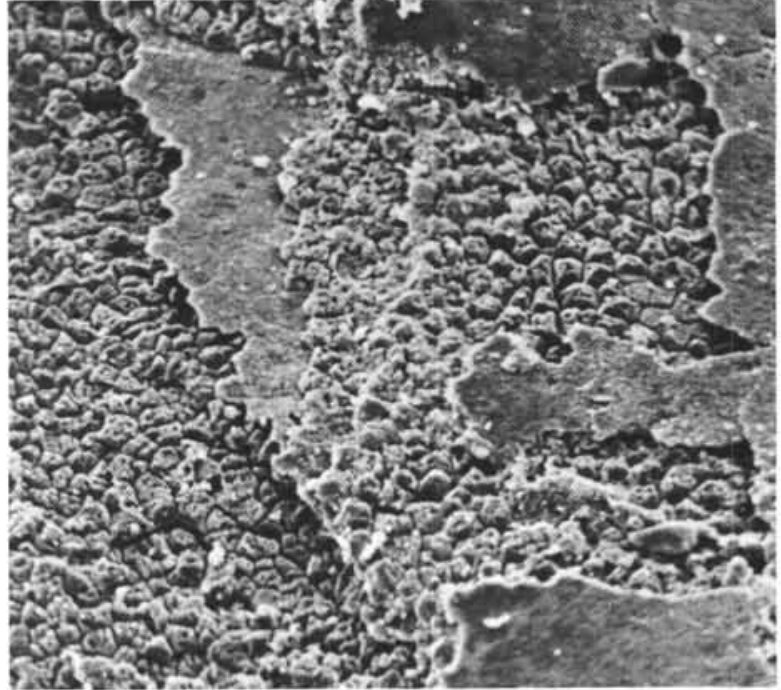
15

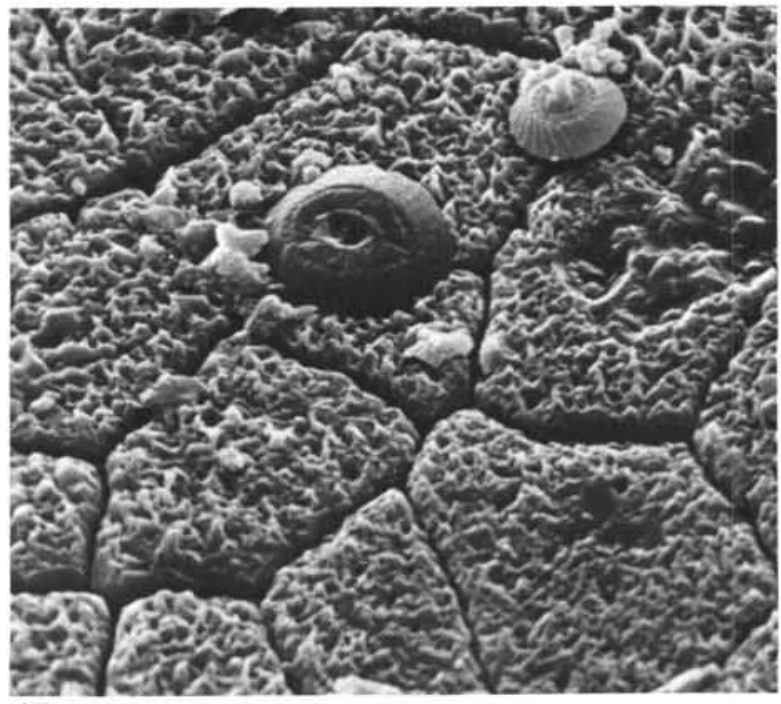
17 